\title{
Chilean crude extract of Ruta graveolens generates vasodilatation in rat aorta at cellular subtoxic concentrations
}

\author{
Ignacio Jofré Fernández ${ }^{1}$, Patricia Navarrete Gómez ${ }^{1,2}$, Jorge Parodi ${ }^{3 *}$, Fernando Romero Mejía ${ }^{1}$, \\ Raúl Salvatici Salazar ${ }^{1}$ \\ ${ }^{1}$ Center of Neurosciences and Peptides Biology, Faculty of Medicine, Universidad de La Frontera, Temuco, Chile \\ ${ }^{2}$ Laboratory of Molecular and Cellular Neurobiology, Department of Molecular and Cellular Neurobiology, Neurobiology Institute, \\ Campus Juriquilla-Querétaro, Universidad Nacional Autónoma de México, Mexico City, Mexico \\ ${ }^{3}$ Laboratorio de Fisiología de la Reproducción, Núcleo de Producción Alimentaria, Escuela de Medicina Veterinaria, Facultad de \\ Recursos Naturales, Universidad Católica de Temuco, Temuco, Chile \\ Email: *jparodi@uct.cl
}

Received 1 October 2012; revised 10 November 2012; accepted 7 January 2013

\begin{abstract}
In Chile elevated percentage of population have cardiovascular diseases, $70 \%$ of this populations is a hypertensive peoples. The Ruta graveolens (Ruta) is a medicinal plant used in different parts of the world with different therapeutics properties like dermatologic as far as anti-helmintic properties. We analyzed the vascular action measuring the tension to identify vasodilator effect of Ruta extract in normtense rat's aorta incubated and measured in isolated organ bath, and evaluating the toxicity effect in CRL-1730 cell line, through enzymatic assay (MTT), confocal microscopy (propidium iodide stain) and flow cytometry (TUNEL assay), including extracellular reactive oxygen species (ROS) production through luminescence assay. The results show with $\mathrm{DE}_{50} 29 \pm$ $0.1 \mu \mathrm{g} / \mathrm{mL}$ evidenced vasodilatation, partially endothelium-depend. The cytotoxicity showed with $\mathrm{DE}_{50}$ $304.6 \pm 2 \mu \mathrm{g} / \mathrm{mL}$ in enzymatic assay (MTT) while evidenced membrane permeability in high concentrations $(1500 \mu \mathrm{g} / \mathrm{mL})$, DNA fragmentation in absence of oxidative stress in only observed when high concentrations of Ruta are used over the cell culture. The vasodilatation activity is executed in subtoxic concentration and partially endothelium-depend without permeability effect in the membrane and deterioration of the cells viability suggesting a complex effect of Ruta preparation in the regulation of vascular tone.
\end{abstract}

Keywords: Vasodilatation; Ruta graveolens; Toxicity, Endothelium

${ }^{*}$ Corresponding author.

\section{INTRODUCTION}

For most people, a blood pressure above 140/90 is considered as hypertension, the upper number, the systolic pressure, is the highest pressure in the arteries when the heart beats and fills the arteries. The lower number, the diastolic pressure, is the lowest pressure in the arteries when the heart relaxes between beats [1]. In Chile, the hypertension prevalence increased from $18.6 \%$ in 1988 to $21.7 \%$ in 2004 . This occurred in all age groups and in both genders. The state of awareness remained stable: $66.9 \%$ in 1988 and $66.6 \%$ in 2004 . The state of treatment increased from $35.6 \%$ (1988) to $59.9 \%$ (2004), and the state of hypertension control from $7.5 \%$ to $30.7 \%$, respectively [2], between the 2009 and 2010, $11.92 \%$ of the population, have a high and $2.5 \%$ very high risk of acquire a cardiovascular disease. Hypertension is a lifestyle-related disease and dietary modifications are effective for its management and prevention.

In the last time, the feeding is essential in the therapy of hypertension. The medicinal plants have been used by indigenous communities since time immemorial. Plants has been used for the control of hypertension or reporting vasodilator effect, like Nige sativa seeds [3], Olea europaea in patients with stage-1 hypertension [4] and Ginko biloba [5], with properties of regulation of arterial pressure. Ruta is a medicinal plant introduce to Chile from Europe, used in the non-traditional medicine. In several reports, Ruta has been described like, antiinflammatory [6], antibacterial [7], antifungal [8], for eyestrain-induced headache [9]. It has also been used as compound for gastric disorders, stiff neck, dizziness and headache [10], however vascular effects are not described. 
Essential components of Ruta, are linear furanocoumarins, psoralen derivatives; bergapten, xanthotoxin, imperotorin and isopimpinelin possessing antiproliferative and photosensitizing, using this property in dermatology and substantially applied in the treatment of leucoderma, psoriasis, vitiligo [11], multiple sclerosis and cutaneous. The more complete molecule obtained from Ruta is the Rutin, these molecule has been reporter like a potassium channels blocker [12], also stimulate a vasorelaxation by nitric oxide pathway [13] and explain systemic in vascular muscles. The Ruta showed positive chronotropic and ionotropic effects on isolated right atria [14]. We proposed effect of the Ruta extract over a vascular tone, mediated by the mixture of the molecules present in the Chilean Ruta, including Rutin and another poliphenols in non toxic condition.

\section{MATHERIALS AND METHODS}

\subsection{Extract Preparations}

The extract was prepared washing Ruta's leaves with deionizer water (Simplicity 185, Millipore, Germany) and dried to $37^{\circ} \mathrm{C}$, later pulverized and extracted with ethanol:water (4:1) for 3 days and filtered in vacuum, concentrated in rotary evaporator and lyophilizated to $-80^{\circ} \mathrm{C}$ for 2 days (Chris Alpha1-2, Osterade, Germany).

\subsection{Tissue Preparation and Vasodilatation Study}

The entire of animals are manager with ethical recommendation from NIH. The Protocol was approved by bioethical commission of the University and present to bioethical national committee in Conicyt and revised by FONDEF committee. Sprague Dawley Rats between 200 to $250 \mathrm{~g}$, were sacrificed through decapitation, and aortas artery was obtained by thoracotomy. The artery was mount in petri dish with solution modified Tyrode balanced salt $\left(\mathrm{NaCl} 137 \mathrm{mM}, \mathrm{KCl} 5.4 \mathrm{mM}, \mathrm{CaCl}_{2} \times\right.$ $2 \mathrm{H}_{2} \mathrm{O} 2.7 \mathrm{mM}, \mathrm{MgCl}_{2} \times 6 \mathrm{H}_{2} \mathrm{O} 0.5 \mathrm{mM}, \mathrm{NaHCO}_{3} 11.9$ $\mathrm{mM}, \mathrm{NaH}_{2} \mathrm{PO}_{4} \times \mathrm{H}_{2} \mathrm{O} 0.45 \mathrm{mM}$ and $\mathrm{C}_{6} \mathrm{H}_{12} \mathrm{O}_{6} \times 1 \mathrm{H}_{2} \mathrm{O}$ $5.55 \mathrm{mM}$ at $\mathrm{pH} 7.3$ and osmolarity $300 \mathrm{mOsm}$ ) in constant oxygenation $\left(5 \% \mathrm{CO}_{2}-95 \% \mathrm{O}_{2}\right)$. The aorta was dissect of underlying medium (connective tissue) and separated in rings of $4 \mathrm{~mm}$. For the experiments without endothelium, was realized the separating rubbing with cotton's swabs. The mounting was realized through silver rods and hanging in organ bath (automatic Organ Bath) to isometric transducer $(50 \mathrm{~g})$ and suspended in Tyrode solution in constant oxygenation $\left(5 \% \mathrm{CO}_{2}-95 \%\right.$ $\mathrm{O}_{2}$ ) to $37^{\circ} \mathrm{C}$. Later, we stimulated the tissue response performing 3 curves of $\mathrm{KCl}(60 \mathrm{mM})$ and maintaining for $10 \mathrm{~min}$, further was washed with Tyrode solution. 1 $\mu \mathrm{M}$ of phenilephryne was added to show maximum tension, $10 \mu \mathrm{M}$ of acetilcholine was added to show presence of endothelium (relaxing in presence of endothelium). To evaluated the vasodilator effect mediated by extract, the aortas rings was contracted with phenylephrine $(1 \mu \mathrm{g} / \mathrm{mL})$ for $10 \mathrm{~min}$ and realized curves dosesresponse in doses of $1,5,10,50,100$ and $1000 \mu \mathrm{g} / \mathrm{mL}$. The acquisition realized through LabChart 6.0 Software. Basal tension was $1 \mathrm{~g}$ later to $10 \mathrm{~min}$ of stabilization.

\subsection{Cell Line and Culture Conditions and Toxicity Study}

The CRL1730 endothelial cells, was obtained from ATCC (Manassas, USA), was cultured in FluoroDish for confocal observation and coverglass for morphology study. The cells were cultured in DMEM High Glucose medium (HyClone, South Logan, Utah, USA) supplemented with 10\% Fetal Bovine Serum (HyClone, South Logan, Utah, USA) and 1\% Antibiotic solution Penicillin-Streptomycin-Amphotericin B, (HyClone, South Logan, Utah, USA). Cell growth was done in $5 \% \mathrm{CO}_{2}$ at $37^{\circ} \mathrm{C}$, changing the culture media every three days. The cells separated and seed in the special cover for 48 hours, and were treated with $19 \mu \mathrm{g} / \mathrm{mL}$ and $1500 \mu \mathrm{g} / \mathrm{mL}$ of Ruta extract for $30 \mathrm{~min}$. Then are washed with PBS 1X fixed with methanol for $3 \mathrm{~min}$. The cells are exposed to propidium iodide $(1.5 \mathrm{mM})$ for $10 \mathrm{~min}$ and washed with PBS 1X. The visualization was realized in Confocal Laser Microscopy (Olympus Fluoview 1000, USA) using 488 of excitation and 617 of emission and stain with Quick Panoptic assay visualized in Optical Microscopy and the photography was acquired with Nikon Camera (DS-Filc, USA). The cell viability was quantified by 3(4,5-dimethylthiazol-2-yl)-2,5-diphenyltetrazolium bromide (MTT) assay (Eugene, Oregon, USA). The cells were cultured on microplates (96 wells) and maintained at $37^{\circ} \mathrm{C}$ in a humidified incubator at $5 \% \mathrm{CO}_{2}$.

The cells were seeded with a density of 50,000 cell/ well. For the cytotoxicity assay, cells were washed two times with PBS 1X (HyClone South Logan, Utah, USA), and $200 \mu \mathrm{l}$ of DMEM High Glucose media were added. The cells were treated with different concentrations of Ruta extract $(0.1,1,10,100,1000$ and 10,000 $\mu \mathrm{g} / \mathrm{mL})$ for $24 \mathrm{~h}$. The media with extract was then discarded and the cells were washed two times with PBS 1X. Aliquots of $100 \mu \mathrm{l}$ of HBSS free calcium and magnesium (HyClone, South Logan, Utah, USA) and $25 \mu$ l of MTT $(5 \mathrm{mg} / \mathrm{mL})$ were added. After incubation for $4 \mathrm{~h}$ at $37^{\circ} \mathrm{C}$ and $5 \% \mathrm{CO}_{2}$, the supernatant was discarding and an aliquot of DMSO (Sigma Aldrich, France) was added. After incubation for $1 \mathrm{~h}$ at room temperature, the absorbance value was obtained in a Biotek Synergy HT (Vermont, USA) microplate reader at $570 \mathrm{~nm}$. 


\subsection{ROS Extracellular Production and TUNEL Assay}

The CRL1730 endothelial cells were used for observed production of ROS extracellular. For measured by luminescence assay, the cells were incubated with luminol (5-amino-2, 3 hydro-1, 4-ftalazinediona, Sigma Chemical Co., St. Louis, MO) $200 \mu \mathrm{M}$ for $15 \mathrm{~min}$ at $37^{\circ} \mathrm{C}$ in darkness in the presences or absence of Ruta extract and immediately quantifying the luminescence in a luminometer Luminoskan (Thermos Scientifics, China), expressing the results as relative luminescence units (RLU). In each analysis, a control without the addition of Ruta extract and positive control cells treated with $\mathrm{H}_{2} \mathrm{O}_{2} 200$ $\mu \mathrm{M}$, were added.

The DNA fragmentation was evaluated using In situ cell death detection kit (Roche, Germany). Then the cells were fixed in formaldehyde $4 \%$ for $15 \mathrm{~min}$ to $4{ }^{\circ} \mathrm{C}$ and permeabilized with Triton X-100 $(0.1 \%$ in $0.1 \%$ of sodium citrate) for $30 \mathrm{~min}$ to room temperature. Later, the cells were washed and incubated with $50 \mu \mathrm{L}$ of $\mathrm{TdT}$ enzyme and dUTP-FITC conjugate for $1 \mathrm{~h}$ to $37^{\circ} \mathrm{C}$ in darkness and humidity. Finally, the cells were washed and measured in Flow Cytometer (FACs Canto II) to 488 $\mathrm{nm}$. In each assay, one negative control without addition of TdT enzyme and one positive control treated with DNasa I (PROMEGA, USA) were added.

\subsection{Statistical Analysis}

The data for the different functional parameters evaluated were expressed as mean \pm SEM. The data were analyzed with GraphPad Prism version 5.02 for Windows (GraphPad Software, San Diego, CA, USA). The differences between the groups were analyzed using the one way analysis of variance (ANOVA) followed by Turkey multiple comparison tests. P values $<0.05$ were considered as significant. For the tension analysis we used LabChart5.0 and data processing with Origin 6 for doses-response.

\section{RESULTS}

\subsection{Ruta Extract Produces Vasodilation in Aortas}

We made a hydroalcoholic extraction from Chilean Ruta graveolens and we obtained total Ruta extract for evaluation of the physiological effect. We present a scheme for the complete protocol (see Figure 1 in methods).

Our extract presented a principal component which was Rutin and a second component, in a minor concentration, was Quercetin, observed in a HPLC Ms/Ms (Figure 1, methods).

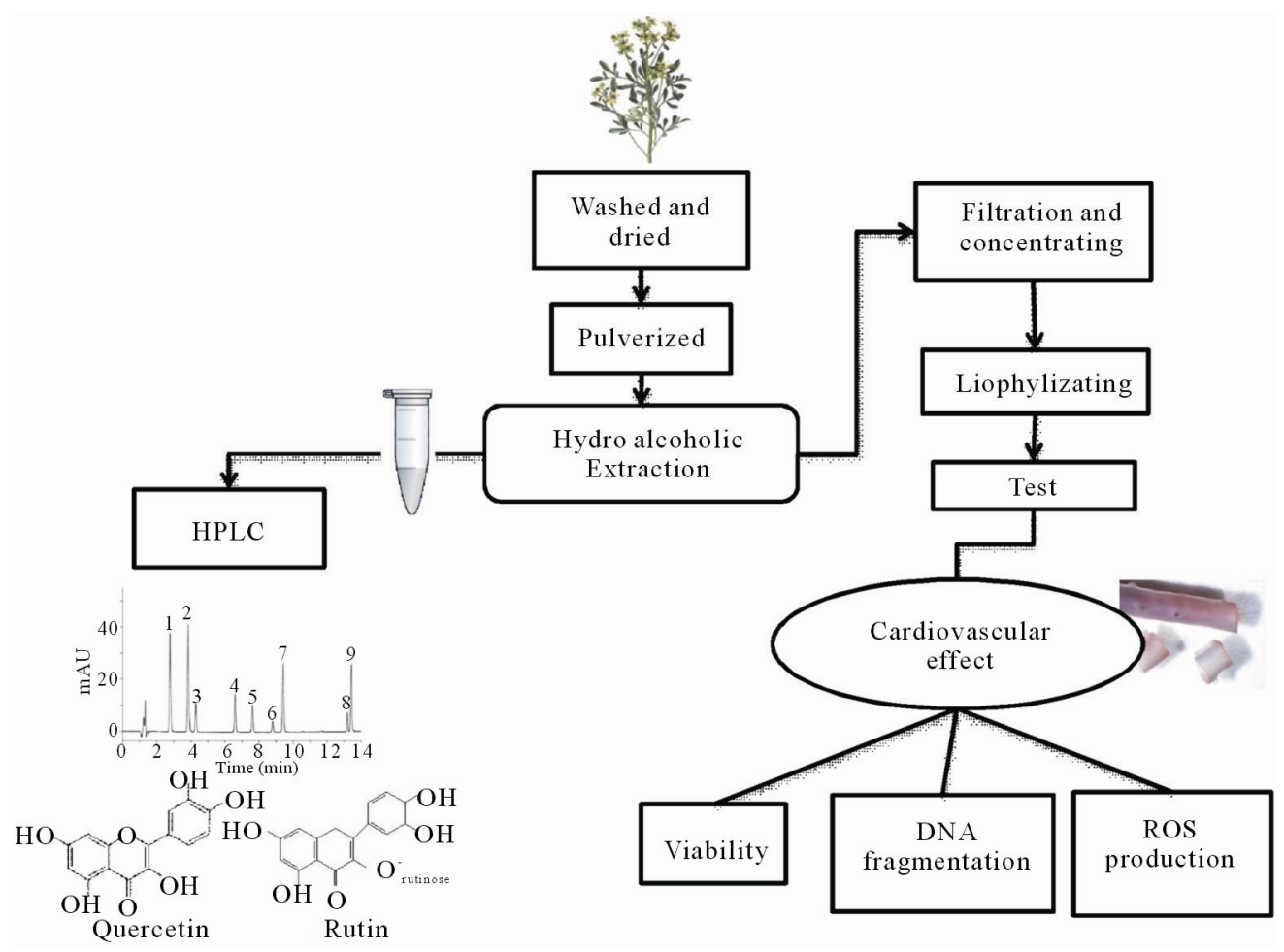

Figure 1. Protocol scheme. Hydroalcoholic extraction was made from fresh Ruta and the contained was observed by HPLC. From these preparations, we separated experiment for study toxicity and function. For test of toxic effect was performed MTT, TUNEL and Luminol dye technique and cardiovascular effect of Ruta extract, was used for functional study. 
Was evaluated the vasodilator effect of Ruta extract against rat aortas rings with and without endothelium. The rings are exposed to different concentration of Ruta extract $(1-50 \mu \mathrm{g} / \mathrm{mL})$ and the tension of the rings are determinate and plotted in a proportional relation with the basal control level (Figure 2(a)). The data were plotted in sigmoidal curve (Figure 2(b)), with doses effective at $50 \%\left(\mathrm{DE}_{50}\right)$ was observed a value of 29 $\mu \mathrm{g} / \mathrm{mL}$ and $40 \mu \mathrm{g} / \mathrm{mL}$ for $\mathrm{DE}_{50}$ with and without endothelium, respectively, suggested a relaxation effect nonendothelium dependent. The Figure 3(a), represent example of curves of rings tension experiment, treatment with Ruta extract $(50 \mu \mathrm{g} / \mathrm{mL})$ when was contracted previous with $\mathrm{KCl} 60 \mathrm{mM}$ and phenylephrine. We proposed a change in the rate of the vasodilation when the rings are exposed to Ruta extract, we observed the decay constant TAU $(\tau)$ when the rings are exposed to Ruta extract and classical molecules like acethylcholine.

We showed in the Figure 3(b) the example of the decay form representative traces in both condition. The bar graph in the Figure 3(c), show the plot of $\tau$ rate (seg) in the experimental condition and we observed that the Ruta's value of $\tau(300 \mathrm{seg})$ was minor. The date suggested effect over vascular tone, this regulation is mediated partially-endothelium depend and the value of the $\tau$, different to the acetylcholine, can be explain for a mechanism complex and more indirect.

\subsection{Loss Viability with Ruta Extract in CRL1730 Cells}

The effect observed over vascular tone indicated a new role of the Ruta extract, however several reports indicated toxic effects of the extract in vivo models [15].

We explored the toxic effects of Ruta extract in the endothelial cellular model. We observed the morphology of the cells stain with Quick Panoptic kit (Figure 4(A), upper panel). The cells are exposed $30 \mathrm{~min}$ to $\mathrm{DE}_{50}$ doses, for vascular effect ( $29 \mu \mathrm{g} / \mathrm{mL}$, Figure 4(Ab)) or to high concentration $(1.5 \mathrm{mg} / \mathrm{mL}$, Figure $4(\mathbf{A c}))$, the microphotography shown alteration of cells when used high concentration of the Ruta extract.

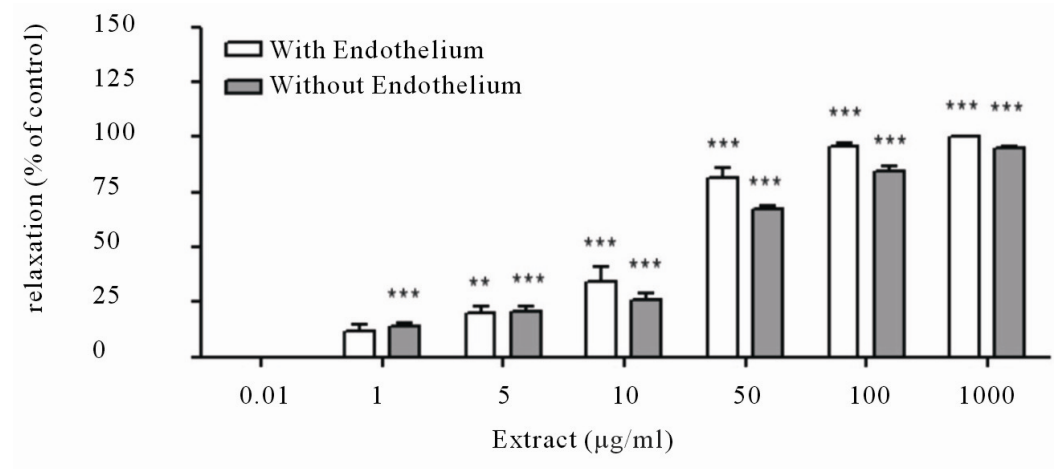

(a)

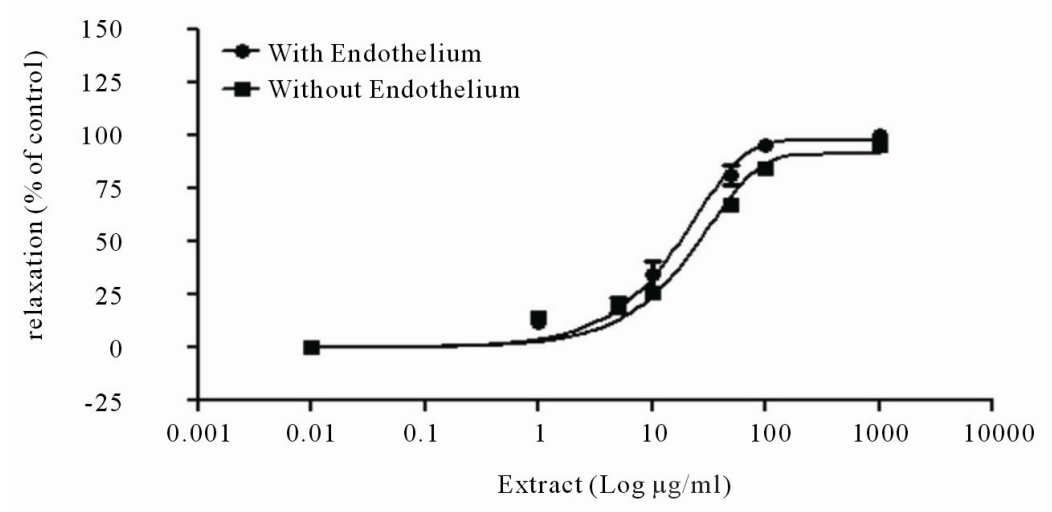

(b)

Figure 2. (a) Vasodilator activity of the extract Effect of Ruta extract in concentrations of $1,510,50,100$ and $1000 \mu \mathrm{g} / \mathrm{mL}$, in conditions of with and without endothelium, with aortas of rats Sprague Dawley and incubated in isolated organ bath; (b) Effect dosis-depend, sigmoidal curve of treatment, $\mathrm{DE}_{50} 19 \mu \mathrm{g} / \mathrm{mL}$ for the dilatation of aortas. Results shown are means \pm SEM $(n=8)$, significant difference $\left({ }^{* *} \mathrm{P}<0.01\right),\left({ }^{* * *} \mathrm{P}<0.001\right)$. 


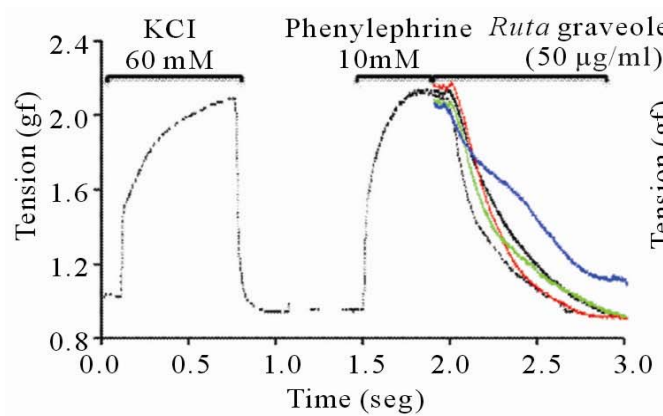

(a)

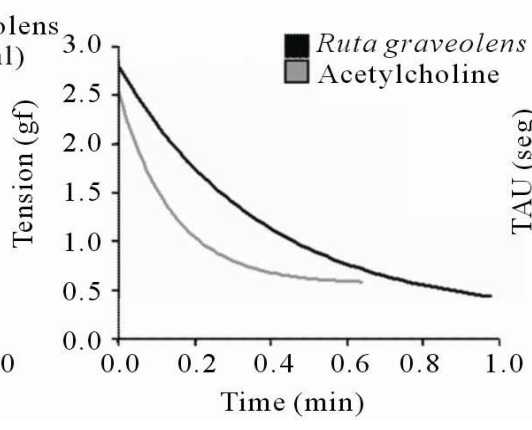

(b)

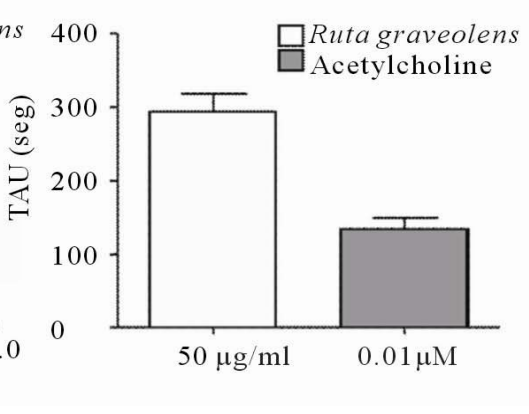

(c)

Figure 3. (a) Representative curve of treatments, preincubation of $\mathrm{KCl} 60 \mathrm{mM}$, wash and contraction with phenylephire $10 \mathrm{mM}$. The effect vasodilator with doses $50 \mu \mathrm{g} / \mathrm{mL}$ of Ruta extract (100\% effect); (b) Tension versus time, effect of sigmoidal curve of treatment, $\mathrm{DE}_{50} 19 \mu \mathrm{g} / \mathrm{mL}$ of Ruta extract for the dilatation of aortas; (c) Time constant (TAU) of the treatments, comparison of vasodilator effect of acetylcholine $(0.01 \mu \mathrm{M})$ and Ruta extract $(50 \mu \mathrm{g} / \mathrm{mL})$ of the decays time.
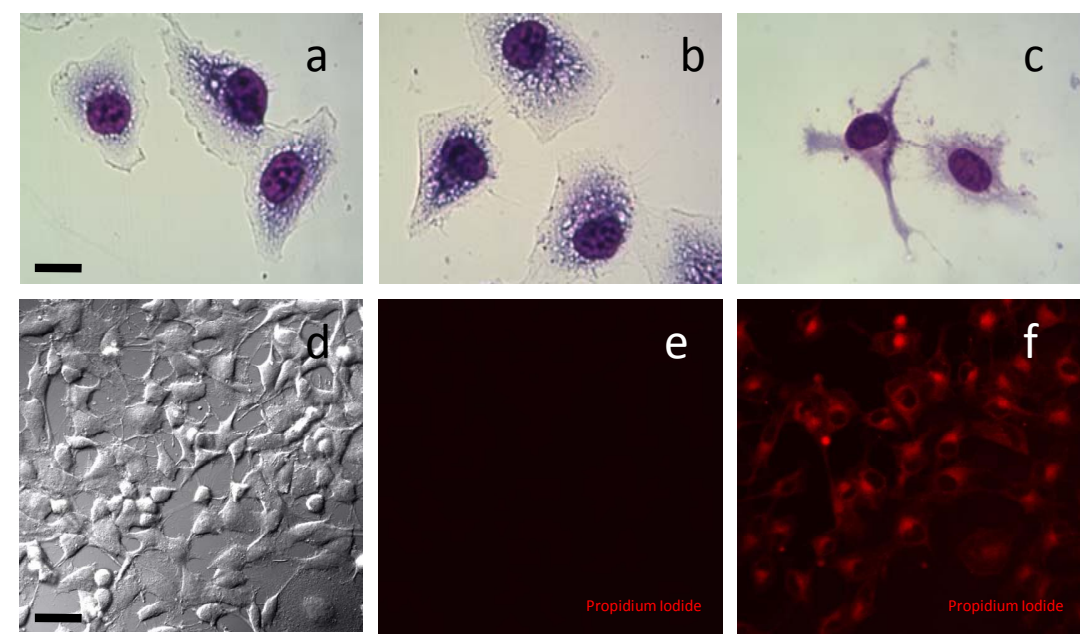

(A)

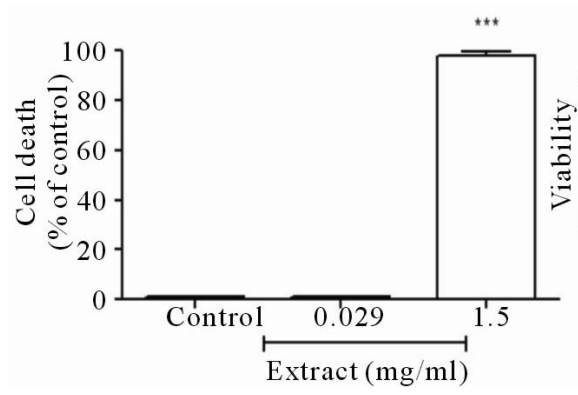

(B)

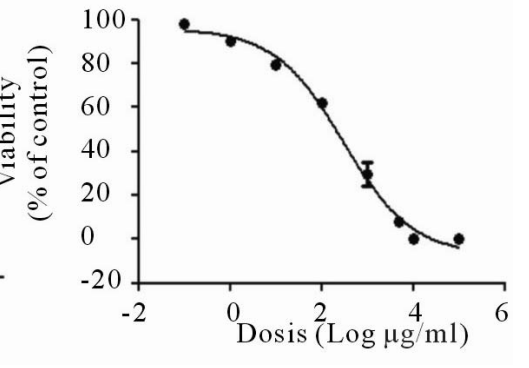

(C)

Figure 4. (A) Microphotography of CRL1730 cells treated with Ruta extract. (Aa) correspond to negative control; $(\mathrm{Ab})$ cells treated with $19 \mathrm{ug} / \mathrm{mL}$ of Ruta extract for 10 min; (Ac) cells treated with $1500 \mathrm{ug} / \mathrm{mL}$ of Ruta extract for $10 \mathrm{~min}$, all of this with Quick Panoptic stain, bars represents $50 \mu \mathrm{m}$ and Confocal microscopy of cells treated with Ruta extract and dye with propidium iodide; (Ad) transmittance of cells without treatment; (Ae) cells treated with $19 \mathrm{ug} / \mathrm{mL}$ of Ruta extract; (Af) cells treated with $1500 \mu \mathrm{g} / \mathrm{ml}$ of Ruta extract, all of this dye with propidium iodide $(1 \mathrm{mg} / \mathrm{mL})$, bars represent $100 \mu \mathrm{m}$. (B) Counting of cell death, evaluation of the cells dye with propidium iodide treatment with Ruta extract. Percentages represent arbitrary fluorescents units relative to control. (C) Curve doses-response of cytotoxicity effect, activity toxic of Ruta extract in concentration of 0.01 to $100,000 \mu \mathrm{g} / \mathrm{mL}$, and measured through MTT assay (enzymatic reduction of formazan), and represent $\mathrm{DE}_{50} 304.6 \pm 2$ $\mu \mathrm{g} / \mathrm{mL}$. Results show are means $\pm \operatorname{SEM}(\mathrm{n}=5)$, Significant differences $\left({ }^{* * *} \mathrm{P}<0.001\right)$. 
When used propidium iodide for see membrane cells permeability (Figure 4(A), lower panel) we observed only effect when the cells are exposed to high concentration of Ruta extract (Figure 4(Af)). We can observe not change in the morphology (Figure 4(Ae)) or in the permeability when used $29 \mu \mathrm{g} / \mathrm{mL}$ of Ruta extract. We observe the number of the cells death, by count of the propidium positive cells (Figure 4(B)) and observed only in the high concentration of Ruta extract a elevated number of death cells. Was evaluated the loss of viability with MTT assay, the results shown loss viability with $\mathrm{DE}_{50} 304.6 \pm 2 \mu \mathrm{g} / \mathrm{mL}$ of extract of Ruta extract. Figure 4(C) show the sigmoidal curve of the response with different concentrations of Ruta extract. The date suggested only toxic effect with high concentration of Ruta extract (over $400 \mu \mathrm{g} / \mathrm{mL}$ ) and moreover we can observe morphological changes. Therefore, the concentrations used for vascular effect not show any toxic effect.

\subsection{Extracellular ROS Production with Ruta Extract}

The regulation of vascular tone is classic described dependent of nitric oxide production (NO) and this gas induce oxide stress [16,17]. We observed relaxations of aortic rings when are exposed to Ruta, and is effect was independent of endothelium. These suggested another molecule involved in the process. However, the toxic effect in high concentration can be mediated by generation of oxide stress. The toxic effect of oxidative stress can be observed by the DNA fragmentation [18]. We used TUNEL assay and observed by flow cytometer. The Figure 5(A) show the dot-plot of the different treatments, and the roman number indicate control non-fluorescent (Figure 5(AI)) effect with $29 \mu \mathrm{g} / \mathrm{mL}$ of Ruta extract (Figure 5(AII)) and effect with $1.5 \mathrm{mg} / \mathrm{mL}$ of extract (Figure 5(AIII)), for evaluate the DNA fragmentation when the cultured are exposed to Ruta extract. The

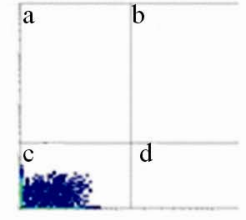

I

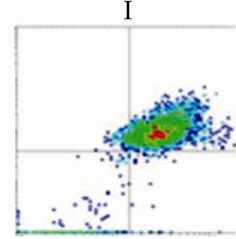

III

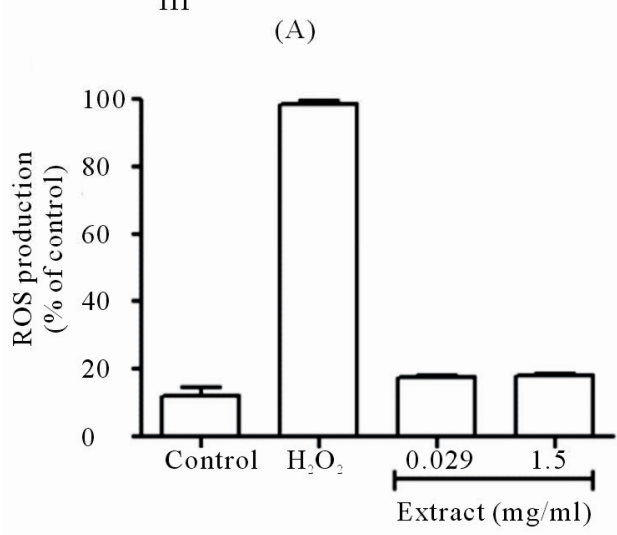

(C)

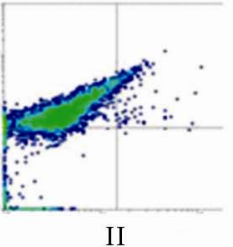

A) Cell Death

B) DNA fragmented and death

C) Nonfluorescent

D) DNA fragmented

Extract $(\mathrm{mg} / \mathrm{ml})$

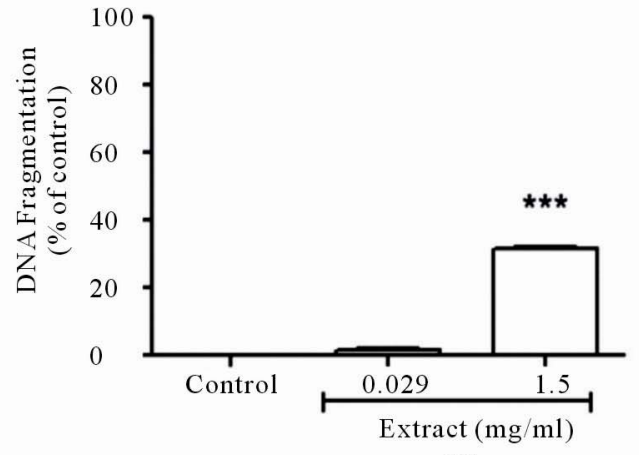

(B)

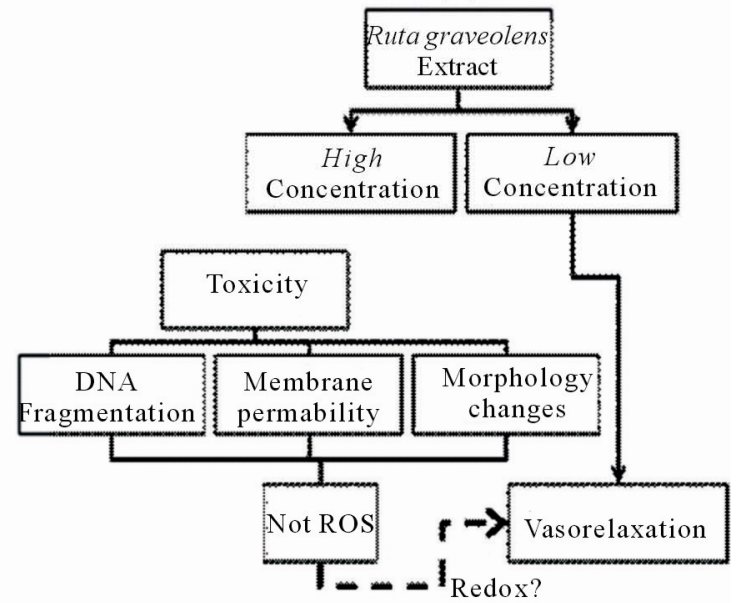

(D)

Figure 5. (A) Representative dot-plot of DNA fragmentation, graphic of dispersion of cells population with DNA fragmentation using TUNEL assay. (B) Graphic of DNA fragmentation in cells treated with Ruta extract, 29 and $1500 \mathrm{ug} / \mathrm{mL}$, and measured through TUNEL assay in a flow cytometer. (C) Extracellular ROS production, the graphic shown effect of Ruta extract on CRL1730 cells, and measured with luminol probe. (D) Model of effect, the model represent effect of vasodilator activity of Ruta extract in concentrations subtoxic without DNA fragmentation and extracellular ROS production. Results shown are means \pm SEM $(\mathrm{n}=$ 5), Significant differences $\left({ }^{* * *} \mathrm{P}<0.001\right)$. 
Figure 5(B) shown a plot when observed the effect of the Ruta extract on DNA fragmentation, only at high concentration $(1.5 \mathrm{mg} / \mathrm{mL})$ induces significant changes in the DNA fragmentation (Figure 5(B)). Was evaluated the extracellular ROS production in the CRL1730 endothelial cell line at basal level and when the cells are exposes to Ruta extract. Extracellular ROS production was measured by luminescence assays and immediately quantifying luminescence.

These measurements are highly sensitive, allowing the presence of different types of ROS simultaneously, the Ruta extract no produces extracellular ROS production (Figure 5(C)) in the low or high concentration, compared to oxidative inductor $\mathrm{H}_{2} \mathrm{O}_{2}(200 \mu \mathrm{M})$.

All the date, suggested a new effect over vascular system, we present overview diagram (Figure 5(D)). The effect are observed when used non-toxic concentration of Ruta extract produces oxide stress, suggested a mechanism mediated by stability of redox condition of the rings.

\section{DISCUSSION}

The plant extract shown specific molecules and direct effect over systemic model, however, the synergism between the different molecules are not completely described [14]. The classic study of preparation of crude extracts and other natural compound, take a total extract and used for describe the physiological effect.

The Ruta plant, contain many molecules like furanocoumarins, psoralen and especially described Rutin. Rutin was described several years ago, as to vasorelaxant via the nitric oxide-guanylyl cyclase pathway and a prostaglandin-mediated mechanism, as well as activation of the ATP-sensitive potassium channel [19] and in addition the traditional medicine in west country used like a abortic and ecbolic [20], these result suggested a dual effect of the Ruta extract and the author proposed a complex mechanism for the different effect in our preparation. In Ruta extract we observed the presences of Quercetin, this is a important antioxidant and present several effect in different model, in vascular physiology has been reported like a vasorelaxant mediated by independent nitric oxide pathway [21], the combination of both compound in the crude extract, generates vasodilation in absence of endothelium and present a synergistic effect in the chilean Ruta extract.

We expected a contraction effect, when the rings without endothelium are exposed to the Ruta extract showing a relaxation in any condition in a non-toxic concentration in according to our results, the work of Chiu in 1997, report arterial pressure reduction when mouse model are exposed to Ruta aqueous extract [22].

The Ruta extract induce relaxation in aortic rings, in a doses-dependent manner, these effect was independent of endothelium cells, suggested a NO independent mechanism and more complex vascular regulation, we proposed a synergistic effect of the different compounds to enhance effect of the Rutin activity and still observed the relaxation in absence of endothelium, we observed a low and high concentration non induce increase of extracellular ROS production and this stabilization of the redox state of the cells are part of the mechanism of the relaxation, in another reports are suggested a relation between redox condition and the vascular tone [23] supporting the idea of indirect effect we find the Ruta extract induce the change in the vascular tone, more slow like a another classic relaxant as acetylcholine, suggested a complex mechanism because the acetylcholine induce a faster relaxation mediated by NO production [24], in our results the more slow response to the Ruta extract are evidence of the more long pathway for generated similar effect. Finally, the Ruta extract a $\mathrm{DE}_{50 \%}$ concentration can induce change in the vascular tone without toxic effect, however, high concentration induce morphological changes, reduction of viability and increases of permeability of membrane but not induce DNA fragmentation. The DNA fragmentation is recognized tool for explored cellular death in a apoptotic pathway [25], our result suggested membrane effect when the cells are exposed to more high concentration and non apoptotic mechanism of cellular death, however in $1.5 \mathrm{mg} / \mathrm{ml}$ of the Ruta extract we can show a significant increases of the DNA fragmentation, is the not more relevant change observed in the cellular death process. We proposed a total extract of the Chilean Ruta graveloens (Ruta extract) is a vascular modulator and the summary of the different compound presences in our extract can be used for new approach to development therapeutic against to hypertension diseases.

\section{ACKNOWLEDGEMENTS}

This work was support by FONDEF D07I1113, Universidad de La Frontera. Patricia Navarrete Gómez has postdoctoral fellow from CTIC-UNAM and BECAS Chile. Jorge Parodi is support for MECESUP-UCT 0708. We are in debt with Dra. Cuevas for review and discussion of this manuscript.

\section{REFERENCES}

[1] Kaplan, N.M. and Victor, R.G. (2009) Kaplan's clinical hypertension, Lippincott Williams and Wilkins, Philadelphia.

[2] Fasce, E., Campos, I., Ibanez, P., Flores, M., Zarate, H., Roman, O. and Fasce, F. (2007) Trends in prevalence, awareness, treatment and control of hypertension in urban communities in Chile. Journal of Hypertension, 25, 18071811. doi:10.1097/HJH.0b013e328244e481 
[3] Dehkordi, F.R. and Kamkhah, A.F. (2008) Antihypertensive effect of Nigella sativa seed extract in patients with mild hypertension. Fundamental \& Clinical Pharmacology, 22, 447-452. doi:10.1111/j.1472-8206.2008.00607.x

[4] Susalit, E., Agus, N., Effendi, I., Tjandrawinata, R.R., Nofiarny, D., Perrinjaquet-Moccetti, T. and Verbruggen, M. (2011) Olive (Olea europaea) leaf extract effective in patients with stage-1 hypertension: Comparison with captopril. Phytomedicine, 18, 251-258. doi:10.1016/j.phymed.2010.08.016

[5] Mansour, S.M., Bahgat, A.K., El-Khatib, A.S. and Khayyal, M.T. (2011) Ginkgo biloba extract (EGb 761) normalizes hypertension in $2 \mathrm{~K}, 1 \mathrm{C}$ hypertensive rats: Role of antioxidant mechanisms, ACE inhibiting activity and improvement of endothelial dysfunction. Phytomedicine, 18, 641-647. doi:10.1016/j.phymed.2011.01.014

[6] Raghav, S.K., Gupta, B., Agrawal, C., Goswami, K. and Das, H.R. (2006) Anti-inflammatory effect of Ruta graveolens L. in murine macrophage cells. Journal of Ethnopharmacology, 104, 234-239. doi:10.1016/j.jep.2005.09.008

[7] Ojala, T., Remes, S., Haansuu, P., Vuorela, H., Hiltunen, R., Haahtela, K. and Vuorela, P. (2000) Antimicrobial activity of some coumarin containing herbal plants growing in Finland. Journal of Ethnopharmacology, 73, 299305. doi:10.1016/S0378-8741(00)00279-8

[8] Oliva, A., Meepagala, K.M., Wedge, D.E., Harries, D., Hale, A.L., Aliotta, G. and Duke, S.O. (2003) Natural fungicides from Ruta graveolens L. leaves, including a new quinolone alkaloid. Journal of Agricultural and Food Chemistry, 51, 890-896. doi:10.1021/jf0259361

[9] Miguel, E. (2003) Rue (ruta 1., rutaceae) in traditional spain: frequency and distribution of its medicinal and symbolic applications. Economic Botany, 57, 231-244. doi:10.1663/0013-0001(2003)057[0231:RRLRIT]2.0.CO; $\underline{2}$

[10] Conway, G.A. and Slocumb, J.C. (1979) Plants used as abortifacients and emmenagogues by Spanish New Mexicans. Journal of Ethnopharmacology, 1, 241-261. doi:10.1016/S0378-8741(79)80014-8

[11] Pathak, M.A., Parrish, J.A. and Fitzpatrick, T.B. (1981) Psoralens in photochemotherapy of skin diseases. Il Farmaco; Edizione Scientifica, 36, 479-491.

[12] Bohuslavizki, K.H., Koppenhofer, E., Hansel, W. and Moller, W.D. (1988) A new approach for the treatment of demyelinating diseases? Journal of Neuroimmunology, 20, 251-252. doi:10.1016/0165-5728(88)90170-1

[13] Amira, S., Rotondo, A. and Mule, F. (2008) Relaxant effects of flavonoids on the mouse isolated stomach: Structure-activity relationships. European Journal of Pharmacology, 599, 126-130. doi:10.1016/j.ejphar.2008.09.021

[14] Chiu, K.W. and Fung, A.Y.L. (1997) The cardiovascular effects of green beans (Phaseolus aureus), common rue (Ruta graveolens), and kelp (Laminaria japonica) in rats. General Pharmacology, 29, 859-862. doi:10.1016/S0306-3623(97)00001-3

[15] Freire, R.B., Borba, H.R. and Coelho, C.D. (2010) Ruta graveolens L. toxicity in Vampirolepis nana infected mice. Indian Journal of Pharmacology, 42, 345-350. doi: 10.4103/0253-7613.71898

[16] Forstermann, U. (2010) Nitric oxide and oxidative stress in vascular disease. Pflügers Archiv-European Journal of Physiology, 459, 923-939. doi:10.1007/s00424-010-0808-2

[17] Rush, J.W., Denniss, S.G. and Graham, D.A. (2005) Vascular nitric oxide and oxidative stress: Determinants of endothelial adaptations to cardiovascular disease and to physical activity. Canadian Journal of Applied Physiology, 30, 442-474. doi:10.1139/h05-133

[18] Higuchi, Y. (2003) Chromosomal DNA fragmentation in apoptosis and necrosis induced by oxidative stress. Biochemical Pharmacology, 66, 1527-1535. doi:10.1016/S0006-2952(03)00508-2

[19] Xia, M.L., Zhou, X.M., Yao, H., Jiang, H.D., Bruce, I.C., Wei, E.Q. and Xia, Q. (2005) Rutin-induced endothelium-dependent vasorelaxation in rat aortic Rings and the underlying mechanism. Conference Proceedings-IEEE Engineering in Medicine and Biology Society, 6, 55955597.

[20] Conway, G.A. and Slocumb, J.C. (1979) Plants used as abortifacients and emmenagogues by Spanish New Mexicans. Journal of Ethnopharmacology, 1, 241-261. doi:10.1016/S0378-8741(79)80014-8

[21] Duarte, J., Pérez-Vizcaíno, F., Zarzuelo, A., Jiménez, J. and Tamargo, J. (1993) Vasodilator effects of quercetin in isolated rat vascular smooth muscle. European Journal of Pharmacology, 239, 1-7. doi:10.1016/0014-2999(93)90968-N

[22] Chiu, K.W. and Fung, A.Y.L. (1997) The hypotensive effects of green bean (Phaseolus aureus), common rue (Ruta graveolens) and kelp (Laminaria japonica) in rats. Phytotherapy Research, 11, 203-206. doi:10.1002/(SICI)1099-1573(199705)11:3<203::AID-P TR81>3.0.CO;2-Z

[23] Gutterman, D.D., Miura, H. and Liu, Y. (2005) Redox modulation of vascular tone: Focus of potassium channel mechanisms of dilation. Arteriosclerosis, Thrombosis, and Vascular Biology, 25, 671-678. doi:10.1161/01.ATV.0000158497.09626.3b

[24] Furchgott, R.F. and Zawadzki, J.V. (1980) The obligatory role of endothelial cells in the relaxation of arterial smooth muscle by acetylcholine. Nature, 288, 373-376. doi: $10.1038 / 288373 \mathrm{a} 0$

[25] Wyllie, A.H., Arends, M.J., Morris, R.G., Walker, S.W. and Evan, G. (1992) The apoptosis endonuclease and its regulation. Seminars in Immunology, 4, 389-397. 